\title{
Bank Risk Assessment: Which Bank Is Better?
}

\author{
Richy Wijaya ${ }^{1}$, Hartini $^{2}$, Jorgie Jovancha $\mathrm{Appy}^{3}$, Lunna Febrin Noviana ${ }^{4}$ \\ \{richy.wijaya@trisakti.ac.id ${ }^{1}$ \}
}

Fakultas Ekonomi Dan Bisnis Universitas Trisakti, Jakarta, Indonesia ${ }^{1,2,3,4}$

\begin{abstract}
Banks manage risk as a whole so that people continue to trust this Institution. Risks must be managed to avoid the worst impacts that contain large costs. The purpose of this research is to of knowing the effect of the internal control system on the effecting of operational risk management in state-owned banks and private banks. The research design used is a hypothesis testing research of the influence of internal control system variables on operational risk management by using multiple linear regression analysis tools. This study also examines differences in employee perceptions of the two variables with several dimensions that exist between state-owned banks and private banks. The sampling method used primary data which was distributed through questionnaires to employees from banks in Jakarta and surrounding areas as well as those outside Jakarta. The findings show that the internal control system significantly influences the implementation of operational risk management. This research also shows that there are differences in the perceptions of employees of state-owned banks and private banks on the internal control system variables on the implementation of operational risk management and their dimensions.
\end{abstract}

Keywords: Internal Control System; Operational Risk Management; Risk Analysis; Risk Assessment; Banking

\section{Introduction}

Risk is always in the opposite direction of the goal to be achieved. Although risk is always there and difficult to avoid, the risk will be reduced if it is managed with the right and proper system. This makes a business actor who directs his business in the banking sector to be more careful in managing all his assets. Risk in the banking world is closely related to money so it has a very large level of risk. Seeing the definition of a Bank as a mediator between parties experiencing a surplus and a deficit in the financial sector, the Bank is often referred to as a trust business between debtors and creditors. If banking financial services cannot carry out both functions as collectors and distributors of funds. Banks can be said to have failed in their operations. Bank Indonesia Regulation (No. Article 1 11/25/PBI/2009) explains that there are eight types of risks that must be faced in the banking business, including; market risk, credit risk, compliance risk, reputation risk, strategic risk, interest rate risk and operational risk. The operation of a bank becomes the most important thing as well as the main element in managing each bank is business line. Clarify operational risk as the risk that arises as a result of inadequate or non-functioning internal processes, human-caused errors, system failures, and 
other events that affect bank operations. Meanwhile, based on world banking regulations, the risks that arise due to failures in internal processes, human resources and company systems are referred to as operational risks. Operational risk is one of the risks that must be immediately managed by the company, so that the company is able and ready to face various kinds of risks that come from outside the company [1].

Risk must be managed because it contains no small cost, therefore the banking industry must manage risk properly to avoid company performance from losses [2]. Operational risk can also have a broad negative impact because the problem is rooted in the failure to implement and implement processes and procedures in a bank activity. This encourages the need to conduct a sharp and extensive research on each application of processes, procedures, and systems established within the bank so that the negative effects of external events that cannot be controlled can be prevented early. Banks must have an ICS which was conveyed that the ICS needs special attention by the Bank, considering that one of the factors causing the Bank's business difficulties is the various weaknesses in the implementation of the ICS [3].

Internal control is an important integrated risk management system that must be implemented by every company to achieve company goals. The importance of implementing internal control within a company is to ensure sustainability and public trust in the company [2]. Bank Indonesia (Lampu SE No.5/22/DPNP dated September 29, 2003) defines the banking ICS as a preventive measure in supervising activities determined by bank management on an ongoing basis with the objectives of 1) protecting and ensuring the security of assets owned by banks; 2) ensure that reports are accurate and have documentation; 3) improve compliance with applicable regulations; 4) reduce the impact/financial loss, irregularities including fraud, and violations of prudential aspects; 5) improve organizational effectiveness and improve cost efficiency.

Each bank has its own internal control strategy. This is adjusted based on the objectives, policies, and size of the complexity of a bank's activities. Where this is determined by the Board of Directors who is approved by the Board of Commissioners on the planned strategy by taking into account the strategic risks to the overall operational management of a Bank. A Bank's internal control needs regular reviews to evaluate any unexpected external changes. According to The Committee of Sponsoring Organizations of the Tradeway (COSO), which includes elements of internal control are control environment, risk assessment, control activities, information and communication, and monitoring [4].

The data needed to identify the Bank's ICS is internal financial information that includes accurate and comprehensive, market information, and bank compliance with operational procedures and applicable regulations. The bank's ICS must also ensure the efficiency of communication channels so that all bank commissioners and directors can understand and comply with applicable policies and procedures. The ICS plays a very positive role for banks if the ICS is implemented optimally, therefore it is necessary for banks to be committed to providing protection and appreciation to whistleblowers so that there is no doubt for anyone to make reports on problems that occur [3].

Given the importance of awareness of all bank parties to risk, banks must internalize the concept of ORM in the bank. By internalizing ORM to all elements of the bank, it allows banks to detect weaknesses and irregularities that occur in a timely manner. Banks that carry out their functions as financial institutions always face several risks that have the potential to increase. So that in anticipating the emergence or increasing of these risks, especially operational risks, a bank's ICS is needed. Therefore, the correlation between the ICS and ORM is very significant.

Abdul Rahim et al. (2018) examines the relationship between the ICS and perceptions of 
ORM at banks and concludes that Malaysian conventional banks have a very good ICS and perceived ORM [5]. Researchers conducting this study wanted to see the relationship between ICSs and ORM. In addition, it will also see whether the implementation of a good ICS will also have a good impact on banking ORM?

Researchers also look at the phenomena that occur in several banks in Indonesia. In 2019 there were cases of embezzlement of funds by branch heads (Kompas.com - 27/10/2019, 20:10 WIB), cases of skiming that occurred in 2020 (iNews TV, Journalists) and cases of fraud committed by banking employees in 2020 (CNN Indonesia) where this case illustrates several important issues related to the ICS and perceptions of ORM, which is still rarely discussed by other researchers. The findings of this study contribute to updating knowledge and provide benefits to the banking industry. This finding has several policy implications related to Indonesian banking and governance policies (advisory board, top management monitoring). Based on the background, the researcher proposes several problem formulations, including:

a. How is the implementation between ORM and ICSs in the state-owned and private banking industry in Indonesia?

b. Does the ICS have a significant impact on ORM?

\section{Literature Review}

Implementation of ORM in each banking branch unit to ensure that the activities carried out are in accordance with the provisions of the ICS set by the center. Researchers find out whether the implementation of the ICS and ORM has been implemented properly? Farren et al (2014) stated that Malaysian conventional banks have good ICSs and perceptions of ORM [6].

\subsection{Agency Theory (Agency Theory)}

Financial institutions in their agency relationships explain the relationship between ORM (agents) and ICSs (principals). Sheedy (1999) states that "agency risk is correlated with information asymmetry and agency complications that usually occur in large public companies compared to self-managed or partnership businesses" [7]. The agent's lack of succes to accord with as stated by to the principal includes several behaviors such as faux pas, inappropriate decisions, and embezzlement. Agency or operational risk is often cited as the main cause of operational losses. "The risk that occurs is caused by several factors, namely poor management decisions, inadequate data, and bad company policies and procedures" [7]

"ICS is a method used by companies to solve agency problems" and that "an efficient decision control system has a significant effect on risk reduction" [8] [9]. Hence, "decisions made at various levels in large companies replicate the dissemination of knowledge and information within an organization" [7]. "separate the decision-making process into four stages, namely initiation of proposals for resource utilization, ratification of decision initiatives, implementation of selected decisions, and monitoring of agency decision performance" [9]. Because incompetence in a bank's ICS will contribute to operational risk [10], every bank needs to have a good ICS to build good ORM [11]. Thus, "agency theory helps in recognizing situations under conditions of high agency risk but also proposes principles to reduce problems with the use of efficient organizational structures" [7]. 


\subsection{Operational Risk Management Perception}

Currently, operational risk is increasingly being recognized and considered as one of the key factors that need to be managed and observed by business actors, especially in the field of financial services. This happens because the impact can have a major impact on the operational activities of an entity. In general, operational risk is a risk that affects all business activities because it is something that is inherent in the implementation of a process or operational activity. According to Fahmi (2010: 54), operational risk is a risk that generally originates from internal company problems, where this risk occurs due to the weakness of the management control system carried out by the company's internal parties [12]. Therefore, the management control system plays a major role in minimizing the occurrence of operational risk within the company, especially in the field of financial services.

The view of ORM includes policy mechanisms, tools, processes, and procedures including management oversight in determining, evaluating, monitoring, describing, and controlling operational risk. With the losses experienced by financial institutions in recent years, the objectives of ORM are reconsidered. "These objectives include better capital allocation, higher capital profitability, avoidance of unexpected losses, avoidance of large losses with small amounts, increase operational efficiency, pay more attention to operational risks during the banking management process and improve service quality for customers and effective information." [13]. However, the view of ORM is not new but there is an increase in the organization of operational risk components within a clearer and organized framework to accelerate competent ORM [14].

\subsection{Internal Control System}

The ICS within a company plays a role in assisting the management in achieving the goals of an organization. According to Romney and Steinbart (2009), "internal control is an organizational plan and various business methods used to protect assets, provide accurate and reliable information, encourage improvements in the company's operational efficiency, and encourage conformity with predetermined policies or organizational goals" [15]. The International Federation of Accountants (IFAC) (2006) highlights that ICSs are designed to help companies fulfill their mission statements [16].

There are three internal control frameworks that are globally recognized by external auditors, internal audit professionals, and management, namely (i) Committee of Sponsoring Organization of the Treadway Commission (COSO) (USA), (ii) Criteria of Control Board Guidance on Control (COCO) (Canada), (iii) Turnbull (UK) Internal control involves processdependent controls and process independent controls.

The ICS framework was established before the accounting scandal that opened the world's eyes to the importance of ICS. This framework defines internal control as a "process" that has been established, will be implemented, and there is a monitoring process carried out by all responsible parties. "Process in a broad sense that goes beyond procedures, consists of basics such as corporate culture and policies as well as systems and tasks" [16].

The major aim of ICS is to help organizations succeed in achieving the goals set by the company. in achieving this goal of course also pay attention to aspects of costs incurred and benefits to be received. According to Fadzil, Haron \& Jantan (2005) stated the main purpose of business ICS is to offer administrative management with practical assurance that the financial data provided is reliable and correct; operational implementation in accordance with plans, policies, procedures, regulations, and laws; assets are protected from theft and loss; 
resources are used carefully and professionally; and the goals and objectives set so that the program or operation can be achieved [17]. "ICS also functions as an early warning system against possible difficulties in achieving business objectives" [18].

Every company has a different set of ICSs. Therefore, the development of an ICS will be designed according to the situation of the organization and will be carried out based on the preferences of the top management of the organization. The party who designs the company's ICS is carried out under the responsibility of the Board of Directors together with the Board of Commissioners. This system must be implemented properly in order for its implementation to run properly. The level of involvement of the Board of Directors or the Board of Commissioners is related to internal controls that differ from one company to another.

The Board of Directors is required to notify the Board of Commissioners regarding the key structure of the ICS because in carrying out its duties the Board of Directors will be supervised by the Board of Commissioners. Internal controls will be more substantial if they are built on codes of conduct and integrity that are endorsed by government agencies and properly disseminated to every staff of the company [19]. Krishnan (2005) said that "excellence in improving the ICS is important in achieving high quality financial reporting. Thus, creating and maintaining a good ICS is the responsibility of top management" [20].

Directly below the leadership of the Board of Commissioners, the audit committee is required to oversee ICS as share of its part. [20] COSO stipulates that intern control consists of five interrelated elements that result from how the organization manages its business and its integration with process management. These elements can be applied to all types of entities despite the fact that smaller organizations are more likely to do so in a simpler way. ICS involves five elements which include:

a) Control Environment

This element provides guidelines regarding the organization that must be well planned so that it can influence employees in their involvement. It is very important to be able to distinguish and avoid errors and inconsistencies. Environmental controls serve as the basis for every other element of the ICS and also provide a sound structure for corporate governance. This supports reducing the level of fraudulent or fraudulent activity in the company's operations and ICS, depending on the environmental controls and their functions [21] [22] [23].

b) Risk Assessment

"This element is related to risk identification, risk analysis, and risk management" [24] [25]. In this setting, management must manage how much risk may occur and strive to maintain risk in these stages.

c) Control Activities

Control activities are required at bank branches to carry out daily operations. This element is explained as procedures and policies to ensure the company's activities can be completed properly based on deliberation to reduce risk. Typically, it contains segregation of duties, process control, physical control, and performance review.

d) Information and Communication

Information systems are very important in leading the company's operational processes. The system implemented must embody an accounting information system to confirm that the accounting action is reliable and valid. An accounting information system consists of documents, accounting approaches, archives, and central functions. Furthermore, the system must be socialized to every member of the organization [24] [26].

e) Monitoring

The ICS must be continuously monitored because it is very important for bank branches to 
ensure proper internal control. In addition, a monitoring process must be carried out to ensure the achievement of the bank's objectives. This can be implemented directly into each activity or regardless of the activity [24] [25].

\subsection{Conceptual Framework}

The framework of this research is to see the relationship between the ICS and bank ORM that is perceived in the banking industry in Indonesia. Those variables are internal control (IC) and ORM (ORM). The following is a schematic of the research conceptual framework:

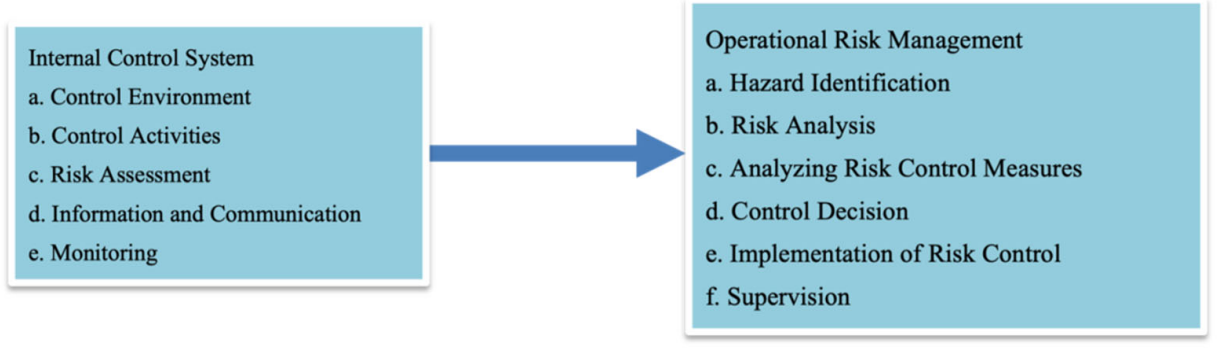

Fig. 1. Conceptual Framework

H1: There is an influence between the ICS and ORM.

$\mathrm{H} 2$ : There is a difference in the effect of the ICS on ORM between state-owned banks and private banks.

\section{Research Methodology}

This study will use primary data in the form of a questionnaire that will be collected from several state-owned banks and private banks in Jakarta. Measurements taken to obtain results from the questions asked are using a Likert scale. Each question posed to the respondents was measured by a measurement scale of strongly disagree, disagree, average, agree, and strongly agree. The following are indicators of the above variables:

Table 1. Variable Measurement

\begin{tabular}{cllc}
\hline Variabel & \multicolumn{1}{c}{ Dimensi } & Sumber \\
\hline Operational Risk & 1. & Hazard Identfication & Guide to Risk Management, \\
Management & 2. Risk Analysis & Queensland Government \\
& 3. Analyzing Risk Control & \\
& 4. Measures & \\
& 5. Control Decision & \\
5nternal Control & 6. Superventation of Risk Control & \\
System & 1. Control Environment & \\
& 2. Control Activity & \\
& 3. Risk Assesment & \\
& 4. Information and Communication & \\
& 5. Monitoring & \\
\hline
\end{tabular}


Testing the hypothesis of this research will be carried out using structural equation modeling (SEM). The reason for using this analytical tool is because the existing data are data in the form of perceptions and ordinal scales. Statistical analysis is a method used to process data which is then interpreted according to the results of data processing. This analysis is used to show the relationship between the independent variable and the dependent variable. The data analysis method used in hypothesis 1 in this study is the Structural Equation Model (SEM) with the help of the Analysis of Moment Structure (AMOS) program. For hypothesis 2 in this study using ANOVA because to test whether there is a difference in the average in each group. SEM is a statistical technique that allows testing of a series of relationships to analyze the relationship between various variables. The goodness of fit test needs to be carried out first on the model used before testing the hypothesis. The goodness of fit test is a test carried out to measure the suitability of the model used in the study with the data that has been obtained [27]

\section{Results and Discussion}

Assessing and measuring data quality on several dimensions of the ICS can use CFA (Confirmatory Model Analysis) with Convergent Validity criteria to see the factor loading on each indicator in a dimension. Convergent Validity assessment can be seen from the factor loading of each construct indicator [28]. According to Hair et al. (2013) the value of factor loading is very sensitive to the size of the sample [27]. The large number of samples in this study as many as 67 participants gave a significant factor loading value of 0.65 so that all statements in the questionnaire were feasible to use (Reliable and Valid).

Table 2. Hypothesis Testing Output From SEM AMOS

\begin{tabular}{ccccc}
\hline & Estimate & ST Error & Prob & Conclusion \\
\hline Internal Control System & 0.869 & 0.147 & 0.000 & $\mathrm{H}_{1}$ Approved \\
\hline$*$ Hypothesis Test Results with regression using AMOS 21
\end{tabular}

Table 2 shows the results of hypothesis testing on the ICS for Internal Risk Management. In the table the value of the coefficient of Internal control is 0.869 , meaning that if the perception of Internal Control increases, the perception of Internal Risk Management increases. Therefore, the ICS with Internal Risk Management in banking in Indonesia has a significant positive relationship and this is in line with research in Malaysia in 2018 entitled "ICS and Perceived ORM in Malaysian Conventional Banking Industry" [29]. ORM is a set of activity chains that have a mission life cycle, including; (1) Hazard identification, analysis, planning, tracking, monitoring, and communicating [30]. The ICS has a significant positive relationship with Hazard Identification contained in a series of ORM activities, as evidenced in a study entitled "ICS and Hazard Identification of Operational Risk in Malaysian Conventional Banking" in 2017 [31]. The results of Figure 2 show that on the five dimensions (MA, IC, CA, RA, CE) Internal control has a significant relationship on the six dimensions of ORM (IR, AR, PR, KK, PPR, PW). 


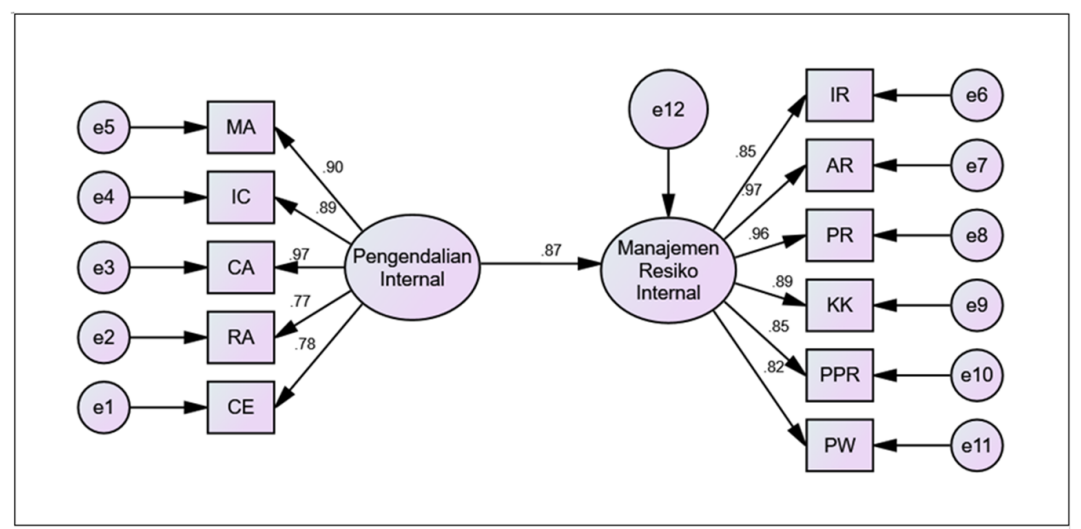

Fig. 2. AMOS SEM Test Results using Standardized Regression results

Table 3 describes a different test table where the results of data processing indicate that there are differences in perceptions between the ICS and ORM. This proves that the indicators used to measure Internal Control have different perceptions with the indicators used to measure ORM.

Tabel 3. Different Test (Mann Whitney test)

\begin{tabular}{lccc}
\hline \multicolumn{1}{c}{ Variabel/Dimensi } & sig & Keputusan & Kesimpulan \\
\hline Internal Control System & 0.010 & Ha diterima & Terdapat Perbedaan \\
Control Environment & 0.002 & Ha diterima & Terdapat Perbedaan \\
Control Activity & 0.001 & Ha diterima & Terdapat Perbedaan \\
Risk Assesment & 0.001 & Ha diterima & Terdapat Perbedaan \\
Information and Communication & 0.000 & Ha diterima & Terdapat Perbedaan \\
Monitoring & 0.000 & Ha diterima & Terdapat Perbedaan \\
Operational Risk Management & 0.006 & Ha diterima & Terdapat Perbedaan \\
Hazard Idetification & 0.000 & Ha diterima & Terdapat Perbedaan \\
Risk Analysis & 0.026 & Ha diterima & Terdapat Perbedaan \\
Analyzing Risk Control Measures & 0.005 & Ha diterima & Terdapat Perbedaan \\
Control Decision & 0.001 & Ha diterima & Terdapat Perbedaan \\
Implementation of Risk Control & 0.019 & Ha diterima & Terdapat Perbedaan \\
Supervision & 0.007 & Ha diterima & Terdapat Perbedaan \\
\hline
\end{tabular}

Tabel 4. Ranking of Descriptive Results for Dimensions of Internal Control System

\begin{tabular}{lcccc}
\hline \multicolumn{1}{c}{ Item } & Bank Type & N & Mean & Rank \\
\hline Control Environment & State-Own & 29 & 4.8966 & 3 \\
& Private & 38 & 4.5263 & \\
Total & 67 & 4.6866 & \\
& Ttate-Own & 29 & 5.0000 & 1 \\
Risk Assesment & Private & 38 & 4.6579 & \\
& Total & 67 & 4.8060 & \\
Information and Communication & State-Own & 29 & 4.8966 & 4 \\
& Private & 38 & 4.4737 & \\
& Total & 67 & 4.6567 & \\
& State-Own & 29 & 4.8966 & 5 \\
& Private & 38 & 4.3947 & \\
& Total & 67 & 4.6119 & \\
\hline
\end{tabular}




\begin{tabular}{|c|c|c|c|c|}
\hline Item & Bank Type & $\mathbf{N}$ & Mean & Rank \\
\hline \multirow[t]{3}{*}{ Monitoring } & State-Own & 29 & 4.9655 & 2 \\
\hline & Private & 38 & 4.5526 & \\
\hline & Total & 67 & 4.7313 & \\
\hline Internal Control System & Total & 67 & 4.7164 & \\
\hline
\end{tabular}

Table 4 shows the ranking results of the ICS data processing using descriptive analysis of 4.7164. This shows that the ICS in both BUMN and BUMS is a very important aspect that needs further attention. In addition, table 4 shows that the Control dimension has the highest ranking value with a mean result of 4.8060 while the Information and Communication dimension has the lowest ranking value with a result of 4.6119. In a subsequent study conducted by (Noor et al, 2017) that "the banking ICS in Malaysia showed a mean result of 4.71" [31]. Meanwhile, in a study in Yogyakarta, Indonesia entitled ICS for Islamic Micro Financing that "the average ICS has been implemented for $73.8 \%$ of all Islamic financial institutions in Yogyakarta" [24].

Table 5 shows the ranking results from Operational Risk Management data processing with an average of 4,76269. This shows that Operational Risk Management in both BUMN and BUMS is a very important aspect that needs further attention. In addition, table 5 shows that the Supervision dimension has the highest ranking value with a mean result of 4.6866 while the Implementation and Risk Control dimension has the lowest ranking value with a result of 4.6119. In addition, the dimensions of Hazard Identification and Control Decision have the same mean result, which is 4.6567 .

Tabel 5. Ranking of Descriptive Results for Dimensions of Manajemen Risiko Operasional

\begin{tabular}{lcccc}
\hline \multirow{3}{*}{ Item } & Jenis Bank & N & Mean & Rank \\
& BUMN & 29 & 4.9310 & 2 \\
& BUMS & 38 & 4.4474 & \\
& Total & 67 & 4.6567 & \\
Risk Analysis & BUMN & 29 & 4.7586 & 4 \\
& BUMS & 38 & 4.4474 & \\
Analyzing Risk Control Measures & Total & 67 & 4.5821 & \\
& BUMN & 29 & 4.8276 & 3 \\
& BUMS & 38 & 4.4474 & \\
Control Decision & Total & 67 & 4.6119 & \\
& BUMN & 29 & 4.8966 & 2 \\
& & & & \\
& BUMS & 38 & 4.4737 & \\
Implementation of Risk Control & Total & 67 & 4.6567 & \\
& BUMN & 29 & 4.7241 & 5 \\
& BUMS & 38 & 4.4474 & \\
Supervision & Total & 67 & 4.5672 & \\
& BUMN & 29 & 4.8621 & 1 \\
& BUMS & 38 & 4.5526 & \\
Operational Risk Management & Total & 67 & 4.6866 & \\
& Total & 67 & 4.6269 & \\
\hline
\end{tabular}

Thus, the five dimensions, namely (Control Environment, Risk assessment, Control Activities, Information and communication, and Monitoring Activities) on Internal Control in 
banking State-Owned Commercial Banks (BUMN) and Private-Owned Commercial Banks (BUMS) where sampling is carried out in Bank BCA, BNI, and Cimb Niaga have strong relationships in the six dimensions, namely (Risk Identification, Risk Analysis, Risk Control Actions, Control Decisions, Implementation of Risk Control and Supervision) Internal Risk Management. Looking at the results of the Hypothesis testing, the results have a significant effect indicating that BUMN and BUMS banks have a good ICS where they have implemented a Risk Assessment to anticipate the dangers of risks that will occur in banking operations, have also communicated all information and control all banking activities. from all forms of environment that is able to maximize operational activities from business lines, subsidiaries, to centralized.

All forms of environment referred to are banking commitments in preserving the environment which are applied to supply chains that involve vendors in banking financial business processes. In addition, the banking sector that we examine is very considerate of environmental aspects in every form of loan, investment, and all types of services/products provided to borrowers. All Policies related to the Environment aim to create a framework that is able to provide business opportunities by avoiding various risks. Overall, Indonesian banks have implemented (Basel Committee, banks top level management, and COSO).

Discussing the differences in perceptions between the ICS and ORM in table 4.4 shows that the banking conditions in Indonesia distinguish the two perceptions by referring to the COSO reference in 1992 on the theoretical framework, namely the Internal Control-Integrated Framework which focuses on internal control as an instrument of evaluation. for organizations, while ORM refers to the COSO reference in 2004 on a new theoretical framework, namely the Enterprise Risk Management-Integrated Framework, which emphasizes that internal control is part of ERM. In addition, in this theoretical framework, ERM is also a collection of all organizational risks.

In an article entitled "Is Risk Management Part of Internal Control or Is It The Other Way Around?" explaining the concepts in both COSO frameworks is confusing because risk management is part of the internal control framework. However, internal control is part of Risk Management [32]. The two seem to have no difference in the article entitled "Risk Management vs. Internal Control'[33]. Meanwhile, in a study conducted with an article entitled "Enterprise Risk Management - A Guide For Government Professionals" that Internal Control is part of ERM and internal control is focused on risks related to financial reporting. While ERM does not only manage one type of risk but all areas of risk [34].

\section{Conclusion}

The conclusion is that although internal control is part of ERM, it does not mean that internal control cannot be applied anymore. Instead, its role should be maximized. To build a good ORM, there must also be good internal control. This is evidenced by the results of the Internal Control coefficient value of 0.869 , meaning that if the perception of Internal Control increases, the perception of Internal Risk Management increases. The test results show the magnitude of the P-value $0.000 / 2<0.05$ (alpha 5\%) then accept $\mathrm{H} 1$ and conclude statistically at the $95 \%$ confidence level there is a positive influence of Internal Control on Internal Risk Management. Banking in this study, both state-owned banks and private-owned banks must pay attention to the management of; Control Environment, Control Activities, Risk Assessment, Information and Communication, Monitoring. So that the implementation of operational risk management can achieve the desired goals. The form of commitment from the 
leadership, communication and quality of existing resources are the keys so that the implementation of internal control can achieve the desired results. In this study also found that the existing variables indicate differences in perceptions between state-owned banks and private banks. So that the work culture that is built in banking will affect the activities in running the banking business.

\section{References}

[1] Fatmarindah. (2010). No Title. Kajian Manajemen Risiko Operasional Pada Divisi Penerimaan, Penimbunan Dan Penyaluran Bbm Di Depot Ujung Berung. https://digilib.itb.ac.id/index.php/gdl/view/18093

[2] Nurmalitasari, D. (2016). Sistem Pengendalian Intern Manajemen Risiko (Studi Di Pt. Bank Dki Unit Usaha Syariah Cabang Pondok Indah Jakarta). Jurnal Ilmiah Mahasiswa FEB, 4(2).

[3] Basel, I. I. (2004). International convergence of capital measurement and capital standards: a revised framework basle committee on banking supervision. URL: Http://Www. Bis. Org/Publ/Bcbs, 107.

[4] Boynton, C. W., Raymond, J. N., \& Walter, K. G. (2003). Modern Au-diting, buku satu, edisi ketujuh diterjemahkan oleh Paul A. Rajoe, Dkk, Penerbit Erlangga, Jakarta.

[5] Rahim, N. F. A., Ahmed, E. R., \& Faeeq, M. K. (2018a). Internal Control System and Perceived Operational Risk Management in Malaysian Conventional Banking Industry. Global Business \& Management Research, 10(1).

[6] Chipeta, C., \& Muthinja, M. M. (2018). Financial innovations and bank performance in Kenya: Evidence from branchless banking models. South African Journal of Economic and Management Sciences, 21(1), 1-11. https://doi.org/10.4102/sajems.v21i1.1681

[7] Sheedy, E. A. (1999). Applying an agency framework to operational risk management. Centre for Studies in Money, Banking and Finance, Macquarie University.

[8] Deumes, R. W. J. (2000). Voluntary reporting on internal control by listed Dutch companies. Citeseer.

[9] Fama, E., \& Jensen, M. (1983). The Booth School of Business of the University of Chicago The University of Chicago Law School CONTRACTING COSTS AND RESIDUAL CLAIMS : THE SEPARATION OF OWNERSHIP AND CONTROL *. Journal of Law and Economics, XXVI(2), 301-325. http://www.jstor.org/stable/725104

[10] Dima, A. M. (2009). Operational Risk Assesement Tools for Quality Management in Banking Services. Amfiteatru Economic Journal, 11(26), 364-372.

[11] McPhail, K. (2003). Managing Operational Risk in Payment, Clearing, and Settlement Systems. Bank of Canada Working Paper 2003-2, 2.

[12] Fahmi, I., \& Hadi, Y. L. (2010). Pengantar Manajemen Perkreditan. Bandung: Alfabeta.

[13] Nicoletta, R. A., \& Cornelia, O. A. (2007). The Operational Risk Management, The Bucharest Academy of Economic Studies.

[14] Bodla, B. S., \& Verma, R. (2008). Operational risk management framework at banks in India. The Icfai University Journal of Financial Risk Management, 5(4), 63-85.

[15] Romney, M., \& Steinbart, P. (2009). Accounting Information Systems (ed.). Upper Saddle River, NJ: PrenticeHall.

[16] IFAC. (2006). Internal Controls - A Review of Current Developments. International Federation of Accountants, August, 1-19. 
http://www.ifac.org/sites/default/files/publications/files/internal-controls-a-revie.pdf

[17] Fadzil, F. H., Haron, H., \& Jantan, M. (2005). Internal Auditing Practices and Internal Control System in Malaysian Listed Company. Managerial Auditing Journal, 20(8), 844-866.

[18] Sani, A. A., \& Chaharmahalie, S. (2012). Internal Accounting Controls. Internatinoal Jounrnal of Information and Communication Engineering, 6(2), 54-57.

[19] Ostapchuk, P. (2004). Integrated Control Guidance-A Management Framework. 1-18.

[20] Krishnan, J. (2005). Audit committee quality and internal control: An empirical analysis. Accounting Review, 80(2), 649-675. https://doi.org/10.2308/accr.2005.80.2.649

[21] Badara, M. S. (2013). Impact of the Effective Internal Control System on the Internal Audit Effectiveness at Local Government Level. Journal of Social and Development Sciences, 4(1), 16-23. https://doi.org/10.22610/jsds.v4i1.731

[22] Sudsomboon, S., \& Ussahawanitchakit, P. (2009). Professional audit competencies: the effects On Thai's CPAS audit quality, reputation, and success. Review of Business Research, 9(3), 66-85.

[23] Amudo, A., \& Inanga, E. L. (2009). Evaluation of internal control systems: A case study from Uganda. International Research Journal of Finance and Economics, 27(1), 124-144.

[24] Wardiwiyono, S. (2012). Internal control system for Islamic micro financing. International Journal of Islamic and Middle Eastern Finance and Management, 5(4), 340-352. https://doi.org/10.1108/17538391211282836

[25] Siegwart, R., Arras, K. O., Bouabdallah, S., Burnier, D., Froidevaux, G., Greppin, X., Jensen, B., Lorotte, A., Mayor, L., \& Meisser, M. (2003). Robox at Expo. 02: A largescale installation of personal robots. Robotics and Autonomous Systems, 42(3-4), 203222.

[26] Guy, D. M., Alderman, C. W., \& Winters, A. J. (1999). Auditing. Harcourt College Pub.

[27] Hair, J. F., Ringle, C. M., \& Sarstedt, M. (2013). Partial least squares structural equation modeling: Rigorous applications, better results and higher acceptance. Long Range Planning, 46(1-2), 1-12.

[27] Hult, G. T. M., Hair Jr, J. F., Proksch, D., Sarstedt, M., Pinkwart, A., \& Ringle, C. M. (2018). Addressing endogeneity in international marketing applications of partial least squares structural equation modeling. Journal of International Marketing, 26(3), 1-21.

[28] Ghozali, I. L. (2012). H.(2012). Partial Least Square: Konsep, Teknik Dan Aplikasi SmartPLS, 2, M3.

[29] Rahim, N. F. A., Ahmed, E. R., \& Faeeq, M. K. (2018a). Internal Control System and Perceived Operational Risk Management in Malaysian Conventional Banking Industry. Global Business \& Management Research, 10(1).

[30] Vaysi, M., \& Moazinezhad, M. (2012). Explore ways to develop tourism industry in Kermanshah: approaching to marketing and prioritizing based on AHP model. The Journal of American Science, 8(8), 875-881.

[31] Rahim, N. F. A., Jaafar, A. R., Syamsuddin, J., \& Sarkawi, M. N. (2017). Internal control system and hazard identification of operational risk in Malaysian conventional banking. International Journal of Supply Chain Management, 6(2), 215-228.

[32] Markiewicz, M., Richard, E., Marks, N., \& Ludwicka-Bradley, A. (2013). Impact of endothelial microparticles on coagulation, inflammation, and angiogenesis in agerelated vascular diseases. Journal of Aging Research, 2013. 
[33] Leitch, M. (2004). When is a good time to talk about saving money on SOX 404 compliance? Balance Sheet.

[34] Jovičić, A., Mertens, J., Boeynaems, S., Bogaert, E., Chai, N., Yamada, S. B., Paul, J. W., Sun, S., Herdy, J. R., \& Bieri, G. (2015). Modifiers of C9orf72 dipeptide repeat toxicity connect nucleocytoplasmic transport defects to FTD/ALS. Nature Neuroscience, 18(9), 1226-1229. 